\title{
Pražské Quadriennale scénografie a divadelního prostoru Imaginace. Transformace. Reflexe
}

\author{
Amálie Bulandrová
}

Pražské Quadriennale scénografie a divadelniho prostoru. 6.-16. 6. 2019. Výstaviště Praha.

Letos v červnu proběhl 14. ročník Pražského Quadriennale scénografie a divadelního prostoru $(P Q)$, celosvětové výstavní a festivalové události, která se věnuje scénografii a divadelní architektuře $\mathrm{v}$ tom nejširším slova smyslu. Zásadní změnou tohoto ročníku bylo místo jeho konání. Akce se totiž po několika letech vrátila na dějiště, kde se v roce 1967 odehrála poprvé, a sice do areálu Výstaviště Praha. Tam se $P Q$ uskutečňovalo tradičně až do roku 2011, kdy se kvůli nepř́íznivým okolnostem přesunulo zejména do Veletržního paláce Národní galerie. Následně se v roce 2015 pod uměleckým vedením Sodji Zupanc Lotker již záměrně na Výstaviště nevrátilo. ${ }^{1}$ Hlavním dějištěm minulého ročníku se totiž stalo samotné centrum města Prahy, především několik tamních barokních paláců, které hostily hlavní soutěžní sekce. Podobně jako např́iklad Mezinárodni bienále výtvarného umění v Benátkách se tak PQ 2015 otevřelo celému městu, jeho širšímu centru, přičemž právě stav historických budov tvořil jeho výrazný vizuální rámec.

Byt' se letos $P Q$ centralizovalo do jednoho areálu vystavěného pro akce podobného typu, tj. velké mezinárodní výstavy (tedy do areálu Výstaviště Praha, kromě Průmy-

1 Okolnostmi byl požár levého křídla Průmyslového paláce. Další výjimkou v ne-konání PQ na Výstavišti Praha je taktéž rok 1991. slového paláce také do všech Křižíkových pavilonů a Malé sportovní haly a okolních prostor), fungoval omšelý stav veletržního areálu podobně dominantně jako barokní paláce předchozího ročníku. Rozhodnutím nové umělecké ředitelky Markéty Fantové se hlavním performativním prostorem stal secesní Průmyslový palác, postavený původně pro Jubilejní zemskou výstavu v roce 1981. Ten ve svém Levém křídle hostil soutěžní Studentskou výstavu, v Pravém hlavní soutěžní sekci - Výstavu zemi a regionů, přičemž jeho Střední hala sloužila coby důležité místo setkávání, otevřené fórum a zároveň prostor pro několik dalších výstav - například taktéž soutěžní Výstavu divadelniho prostoru. ${ }^{2}$

Nutno však hned dodat, že právě tato středová budova tvořila pouze jedno z mnoha performativních dějišt, hlavní snad díky své prostorové pozici, ke které se prostřednictvím konání nejrůznějších performancí sbíhaly přilehlé budovy. Otázka tvarů, velikostí, proporcí a jejich vzájemných vztahů, stejně jako otázka vlastností samotných prostorů fungovaly

2 Dále se zde nacházela Výstava děl oceněných Cenou za nejlepši scénografickou publikaci, Knihkupectví PQ, kavárny, konaly se zde také různé performativní akce. Výraznou akcí byl např́klad „módní koncert“ nazvaný Kolekce Taboo, který kombinoval dílo kostýmní návrhářky Fruzsiny Nagy a dirigentky Dóry Halas. 


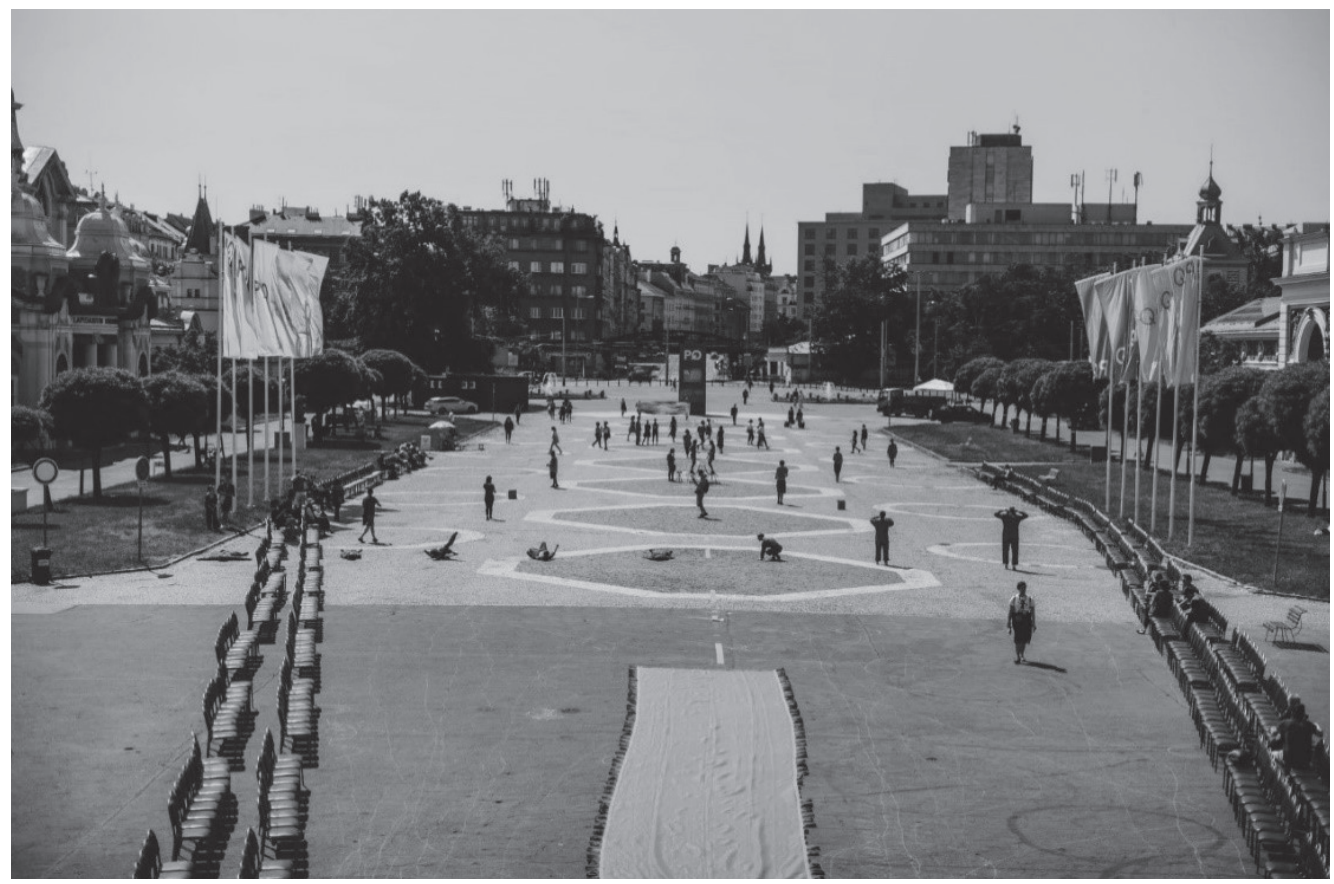

Obr. 1: Foto Saša Dobrovodský

jako pomyslný rámec celého uvažování o dějišti $P Q$. Jinými slovy geometrizace areálu, potažmo celého vizuálního stylu letošního $P Q$, určovala i jeho obsahovou náplň.

Jak uvedl architekt $P Q$ Petr Bakoš, jednalo se o princip zlatého řezu, se kterým $\mathrm{v}$ rámci příprav akce zejména pracoval (Programová brožura PQ 2019 2019: 6). Návštěvníci díky tomu započali svou účast na $P Q$ již procházkou po plaze před Průmyslovým palácem, jež tvoří hlavní přístupovou cestu do areálu. Plaza byla totiž prostorem projektu Formace, který zkoumal, „jak pohyb, struktury a vzorce zasahují do každodenního života“ (Programová brožura PQ 2019 2019: 69). Jeho kurátoři se zabývali různými vzory, které můžeme zhlédnout jak v přírodě, tak ve městě či v architektuře. Následně vytvořili tento urbanisticko-choreografický projekt, složený z několika performativních akcí. Návštěvník se setkával s plochou, která byla definovaná rušením a třením jednotlivých tvůrčích zásahů, jež vznikalo jak přímými akcemi, tak „stopami“ zde zanechanými po uplynulých uměleckých intervencích.

Pokračoval-li návštěvník po tomto „mole“ rovně, mohl přes Střední halu Průmyslového paláce a Křižíkovu fontánu dojít až ke dvěma pavilonům, tvořícím pomyslnou skene celého prostoru. Jednalo se o Křižíkův pavilon $\mathrm{C}$ hostící $P Q$ Dětem a školám a Křižíkův pavilon $\mathrm{D}$, ve kterém byla umístěna výstava projektu Emergence. Podél takto definované hlavní osy PQ 2019 se zrcadlově nacházely další čtyři jeho dějiště: po levé straně jednak již zmiňované Levé kř́ídlo (stan) Průmyslového paláce se Studentskou výstavou a Křižíkův pavilon B 

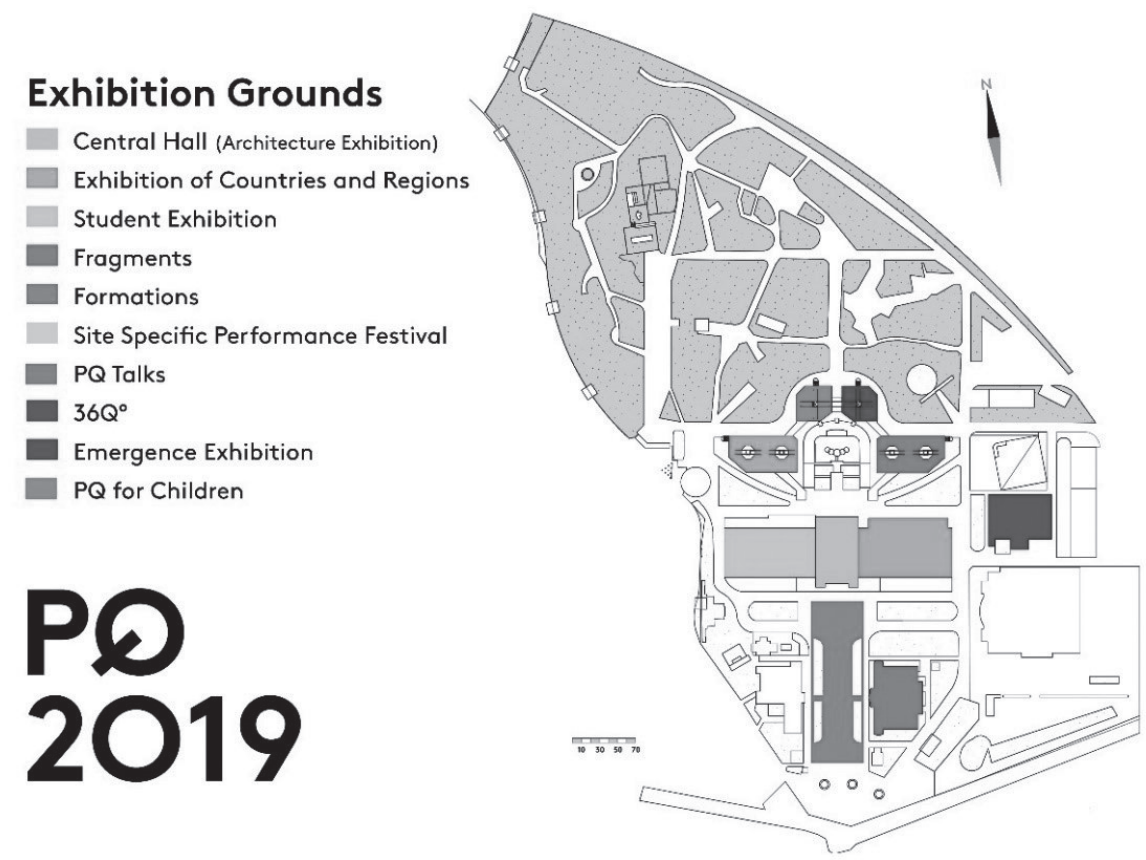

Obr. 2: Zdroj: Web PQ

s druhou částí Výstayy zemi a regionů. ${ }^{3}$ Po pravé straně mohl návštěvník dále navštívit také již zmiňované Pravé křídlo Průmyslového paláce, kde byla umístěna první část Výstavy zemi a regionů, nebo Křižíkův pavilon E, kde se odehrávaly diskuze sdružené pod PQ Talks.

Cílem projekt $P Q$ Talks bylo vytvořit platformu pro kritickou diskuzi o nejrůznějších rovinách scénografie, pro širokou (mezioborovou) debatu a výměnu uměleckých i akademických názorů, postřehů, komentářů a koncepcí. Kurátoři Barbora Příhodová a Pavel Drábek proto oslovili několik přednášejících z celého světa, at’ již profesionálů nebo studentů, umělců či teoretiků, a pozvali je, aby pohovořili na téma, kterým se aktuálně zabývají. Vý-

3 Podobu stanu získalo Levé křídlo Průmyslového paláce po ničivém požáru v roce 2008. sledkem bylo několik diskuzních panelů, kulatých stolů, programových prezentací či krátkých „flashtalks“, sdružených do tematických bloků. Kriticky se hovořilo například o spolupráci ve scénografii napříč obory, o kostýmu jako scénografii, o scénografii a politice, o nových médiích, o tom, čím scénografie byla a čím by mohla být, nebo například o současných trendech v oboru (Programová brožura PQ 2019 2019: 83).

Z výše vytyčeného zlatého řezu areálu Výstaviště Praha, respektive z jeho zrcadlové struktury, vybočují dva prostory, ve kterých se $P Q 2019$ také odehrálo. A to Lapidárium Národního muzea, které se nachází po pravé straně prostranství před Průmyslovým palácem, a kde byla umístěna výstava Fragmenty, a taktéž na pravé straně umístěná Malá sportovní hala, jež hostila projekt $36 Q^{\circ}$. V prvním případě šlo 


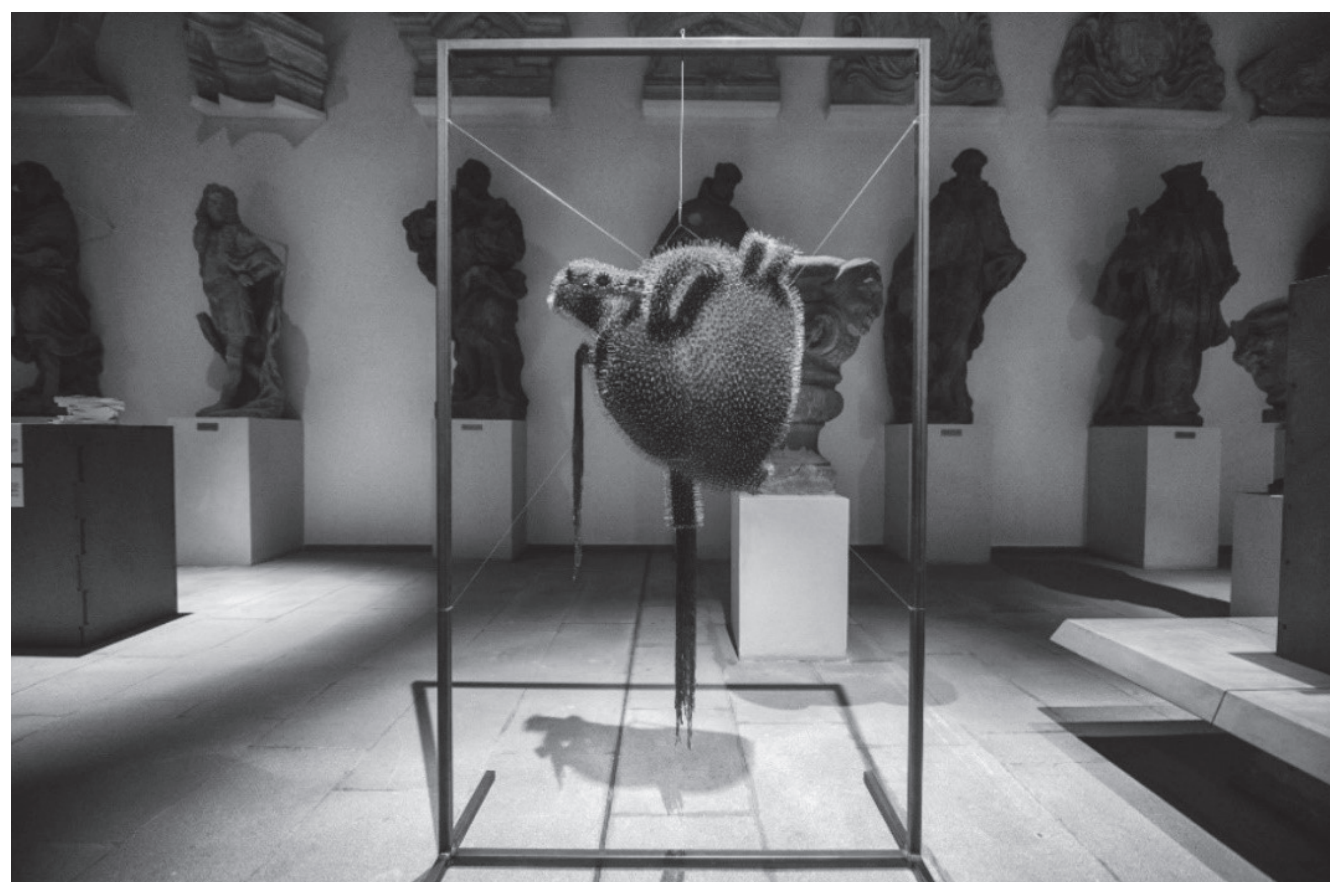

Obr. 3: Foto Alžběta Jungrová

o výstavu připravenou pod kurátorským vedením Kláry Zieglerové. Skládala se ze scénografických fragmentů, tedy předmětů, které zbyly po představení. Konkrétně měla každá zúčastněná země za úkol vybrat jeden artefakt, „kultovní či přelomové dílo z oblasti scénické výpravy, kostýmního výtvarnictví, světelného nebo zvukového designu, které vytvořila některá z nejvěhlasnějších žijících legend oboru [...]“ (Programová brožura PQ 2019 2019: 55).

\section{Fragmenty}

Výstava Fragmenty vznikla jako součást většího projektu Emergence, jehož hlavním cílem je uchování pamětí významných umělců, jejichž práce inspirovala a přispěla k vývoji scénografie jako uměleckého oboru. Návštěvníci této výstavy mohli kon- frontovat nejrůznějšími modely, nákresy, kostýmy a rekvizity se stálou expozicí Národního muzea, jež je v lapidáriu umístěna a kterou tvoří převážně kamenné historické objekty. Mezi ně totiž byly ony scénografické fragmenty rozmístěny. Přestože bylo osvětlení směřující na stálé výstavní exponáty vypnuté, tj. naprríklad obrysy sochařské výzdoby Staroměstské mostecké věže jako by pouze vystupovaly ze tmy, tvořily „zhasnuté objekty“ nedílnou součást výstavy. Dohromady s výraznou atmosférou toto výstavní řešení působilo dojmem, který mohl být vnímán jako přehlídka „dřívějšího“ způsobu vystavování scénografie, od kterého se současné vedení $P Q$ odklání. To se ostatně dočítáme hned v úvodu letošní programové brožury, kde je vymezeno, že hlavní snahou letošního ročníku $P Q$ je především nabídnout unikátní zážitek: „Naším záměrem není představit scénografii 
prostřednictvím artefaktů, a už vůbec ne jako dekorace a kostýmy tradičního divadla“ (Programová brožura PQ 2019 2019: 8). Jak vysvětlila umělecká ředitelka $P Q 2019$ Markéta Fantová, úkolem kurátorů jednotlivých zemí nebylo vytvořit důmyslnou výstavu, nýbrž jedinečnou scénografickou krajinu, v podstatě prostředí. ${ }^{4}$

\section{$36 Q^{\circ}$}

Pod kurátorským vedením Markéty Fantové a Jana K. Rolníka vznikl v Malé sportovní hale kolektivní projekt nazvaný $P Q$ $36 Q^{\circ}$ („tři sta šedesát“), jehož cílem bylo propojit uměleckou představivost a nejnovější technologický pokrok. Tendence experimentovat a prozkoumávat široké spektrum možností, jež moderní technologie nabízejí, vyústil v koncept zaměřený především na mladou generaci nastupujících tvůrců. Jádrem projektu se následně stala audiovizuální, taktilní a světelná instalace/ prostředí s názvem Blue Hour (Programová brožura PQ 2019 2019: 79).

Sportovní hala se v rámci projektu proměnila $\mathrm{v}$ experimentální interaktivní prostředí představující uměleckou a technickou stránku scénografie. Vzhledem k několika „ostrůvkům“, tvořícím další svébytná prostředí uvnitř samotné instalace, byla scénografie v podání $36 Q^{\circ}$ také aktivním činitelem, tvưrcem dalších smyslových prostorů. Ty byly řízeny určitou dramatickou strukturou, měnily se a v průběhu času vyvíjely (Programová brožura PQ 2019 2019: 79). Projekt byl založen na týmové spolupráci, propojující jak zkušené umělce, tak začínající designéry, kteří byli vybrá-

4 Uvedla Markéta Fantová pro Český rozhlas Vltava. (ŠTEFANOVÁ 2019b) ni na základě otevřené výzvy. „Kurátorský tým plánuje experimentovat s měnícími se hranicemi mezi ,nehmotným‘ či ,virtuálním‘ a ,skutečným‘ světem a zkoumat schopnost scénografie využívat technologie v kulturní produkci“ (Programová brožura PQ 2019 2019: 80). Toho mělo být dosaženo prostřednictvím interakce různých oblastí designu, jako je světelný design, video projekce, zvukový design, virtuální realita či taktilní design a kreativní kódování s lidským tělem (Programová brožura PQ 2019 2019: 80).

Vše se uskutečnilo pod vedením francouzského vizuálního umělce Romaina Tardyho, který koordinoval skupinu tvůrců z mnoha oborů. Jednalo se konkrétně o šest pracovních skupin, které pokrývaly různé druhy designu, přičemž každá z nich měla svého „vedoucího“: Pavla Beranová (světelný design), Rob Kaplowitz a John Richards (zvukový design), Shannon Harvey (System integration), Tereza Stehlíková (taktilní hmatatelné prostředí), Jaris Weijdom a Paul Cegys (VR/AR Gallery - technologie virtuální reality). Jedna z autorek projektu, česká světelná designérka Pavla Beranová, přirovnává např́íklad pojednávaný umělecký počin ke krajině, kterou může návštěvník procházet a nechat na sebe přitom působit různá média, zažívat různá smyslová dobrodružství. Jak umělkyně zdůraznila, jedná se o imerzní prostor - prostor vnoření. ${ }^{5}$

V prrípadě projektu Blue Hour jsem se pokusil otočit obvyklý postup, kdy se světlo aplikuje na stávající objekt či strukturu: samo světlo se stalo pro jednou stavebním materiálem? Toto imerzivní prostřední je

5 Pavla Beranová pro Český rozhlas Vltava. (ŠTEFANOVÁ 2019b) 


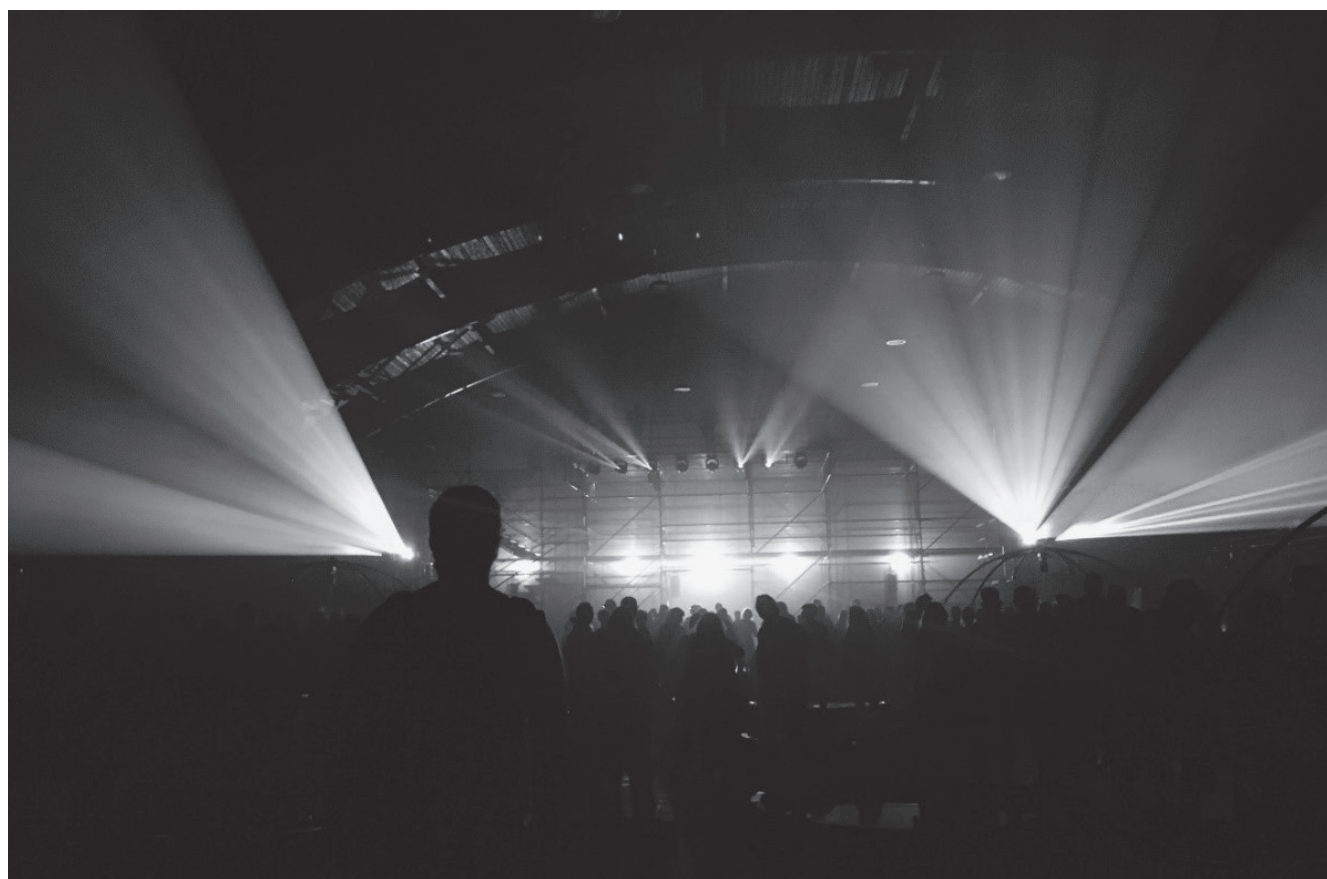

Obr. 4: Foto archiv autorky

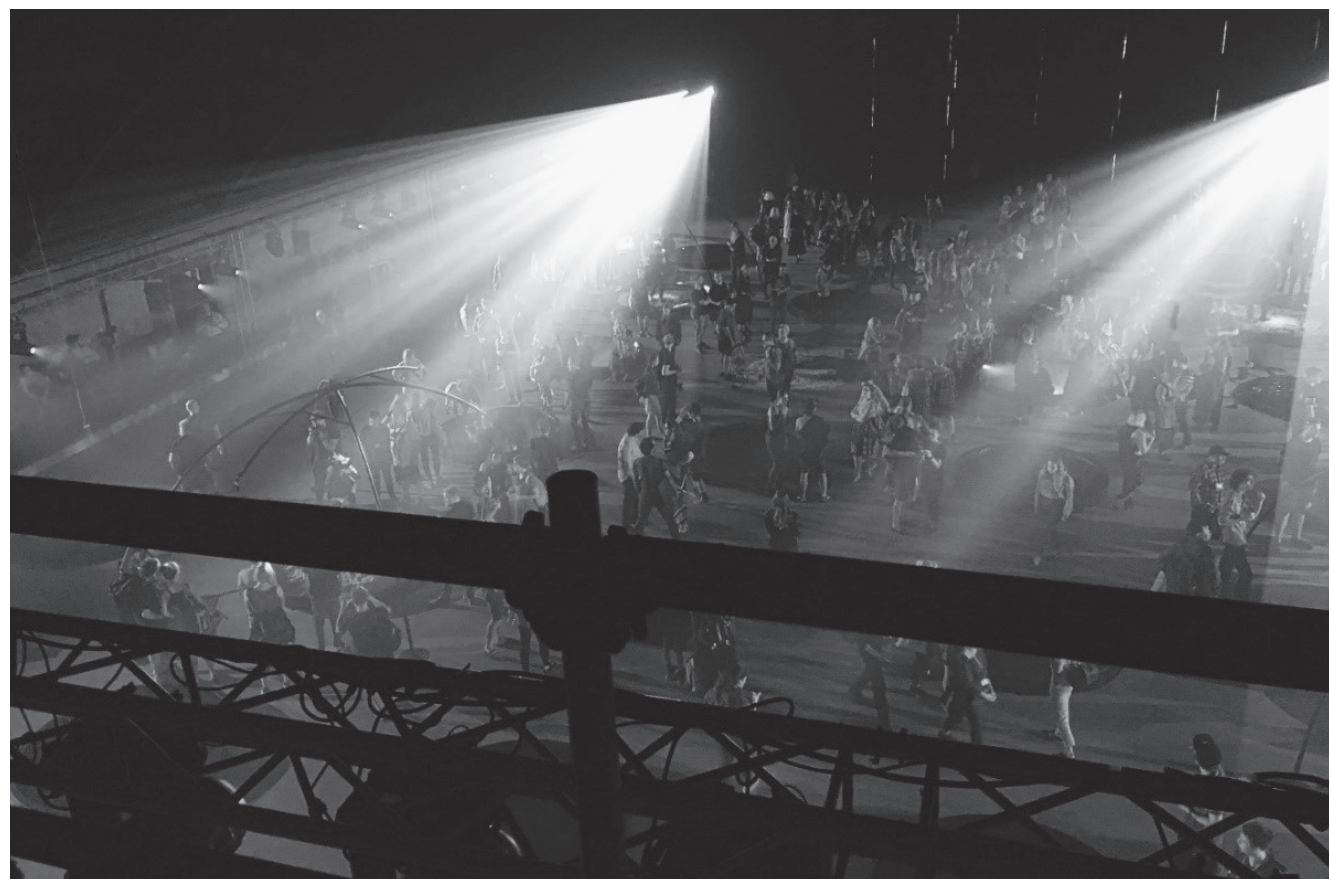

Obr. 5: Foto archiv autorky 
koncipováno jako experimentální prostor pro světlo: všechny prvky instalace slouží světlu: jako jeho zdroj nebo jeho přijímač. [...] publikum prozkoumává prostředí, čímž se spolupodílí na jednom z mnoha cyklů - tvoří krásu prchavého prostoupení světelnými paprsky, na několik vteřin mění prostor a postupuje po cestě, kterou nelze předpovědět. (Programová brožura PQ 2019 2019: 80)

\section{Imaginace.Transformace.Reflexe}

Kurátorské zaměření letošního ročníku $P Q$ přibližuje umělecká ředitelka Markéta Fantová termínem „porézní hranice“, již spatřuje mezi týmovou spoluprací a snahou umělce individuálně vyniknout a kterou se v rámci $P Q 2019$ rozhodla prozkoumat blíže (Programová brožura PQ 2019 2019: 9). Chápeme-li přeneseně hranici jako nějaký pevný či (polo)tuhý bod, potažmo materiál, znamenala by jeho pórovitost přítomnost mnoha drobných a rovnoměrně rozložených otvorů nejrůznějšího tvaru a původu. $\mathrm{V}$ prrípadě $P Q$ tedy můžeme uvažovat o jedné platformě tvořené mnoha menšími jednotkami, které definují její povrch, ale i obsah. Každá dílčí drobná struktura je ale sama o sobě také porézní hranicí, například právě ve výše zmiňovaném smyslu týmové spolupráce a vlastní osobitosti v rámci umělecké tvorby. Markéta Fantová dále vysvětluje, že takovou hranici můžeme v dnešním světě spatřovat i například v hledání rovnováhy mezi dvěma tvořivými silami: „láskou (philotes) a konfliktem (neikos), tedy abstraktně myšleno rovnováhu mezi kolektivní tvorbou, kolektivním zážitkem a vlastní identitou“ (Programová brožura PQ 2019 2019: 9). A právě tato rovnováha se podle umělecké ředitelky stala výzvou pro všechny soutěžní výstavy $P Q$ 2019, tedy pro scénografické práce z více než 72 zemí.

Zatímco byl předchozí ročník $P Q$ doplněn podtitulem HudbaPočasiPolitika, který vymezoval tři hlavní témata $P Q 2015$ a tedy obsahové zaměření na nehmatatelné, nemateriální, neviditelné části scénografie, které ji (nás) přesto ovlivňují, a na jejich společenskou funkci, nesl letošní podtitul název Imaginace.Transformace.Reflexe. Namísto otázky „Proč děláme věci tak, jak je děláme?" se tedy obsahové směřování letošního ročníku soustředilo na otázku: „Komu je naše práce určena?" (Programová brožura PQ 2019 2019: 9) Podle slov Markéty Fantové stálo v popředí úvah o letošním ročníku ocenění Zlatá Triga, udělované již více než 50 let coby hlavní cena $P Q$. Triga představuje trojice, v př́ípadě ocenění koňské trojspřeží, a v rámci PQ 2019 pak symbol propojení třech kreativních sil a třech významných etap v životě a kariéře scénografa: „Imaginace je pro nás zdroj, odkud inspirace přichází, a právě imaginaci jsme podřídili všechny mladé designérské nápady. Transformace nebo též proměna symbolizuje fázi, kdy se nápad promění v něco konkrétního. Přičemž reflexe znamená pohled zpět, ale také nabytí určité zkušenosti."

Jak konkrétně vypadala realizace zadané umělecká koncepce mohl návštěvník prozkoumat od 6. do 16. června 2019, přičemž od 11. června 2019 již bylo známo, které expozice získaly ocenění od mezinárodní poroty. ${ }^{7}$ Kromě tradičních cen

6 Markéta Fantová pro Český rozhlas Vltava. (ŠTEFANOVÁ 2019a)

7 Mezinárodní porota $P Q 2019$ ve složení Kate Bailey (předsedkyně), Dorita Hannah, Tim Foster, Jim Clayburgh, Liu Xinglin, Sofia Pantouvaki, Robert Kaplowitz, Yaron Abulafia, Sodja Lotker, Omar Rajeh a Monica Raya ocenila celkem 28 vystavených projektů. 


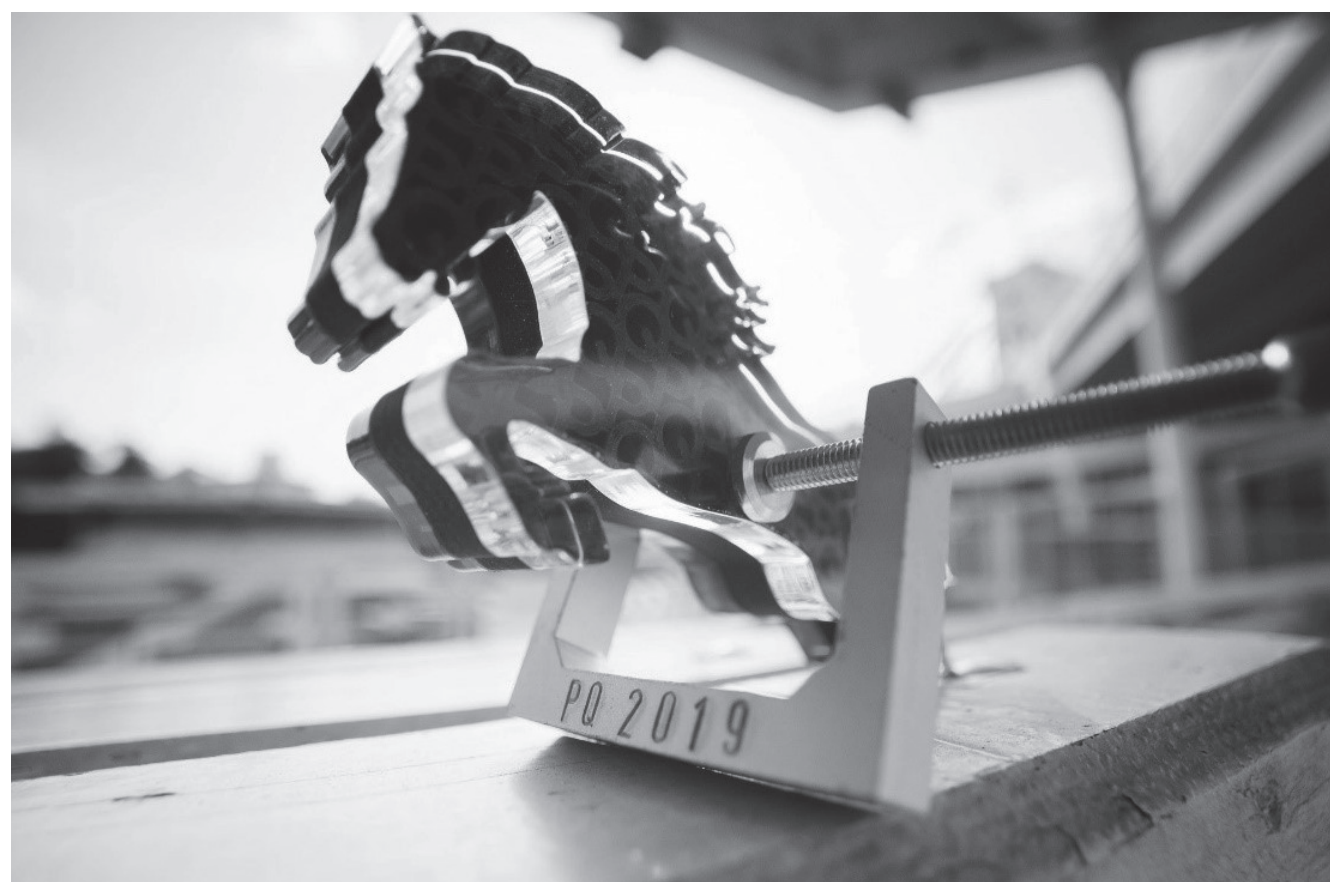

Obr. 6: Cenu navrhl Petr Bakoš. Foto Jan Hromádko

jako je např́ílad právě Zlatá triga či Cena za nejlepší expozici, udělila porota také zcela nové ceny, jako Ocenění za nejvýraznější talent nebo Ocenění za Imaginaci: „Dali jsme porotě možnost, aby utvořili nějaké ceny sami, právě podle toho, co vidí jako nově se vyvíjející část scénografie [...]. Inovace nás určitě zajímá a ze všeho nejvíc nás zajímá týmová spolupráce a spolupráce vůbec." ${ }^{8}$

A právě v kategorii Ocenění za Imaginaci ve Studentské výstavě, kde byly oceněny celkem tři projekty, získali cenu i reprezentanti České republiky - skupina „Intelektrurálně“, jež pro Studentskou výstavu $P Q 2019$ vytvořila expozici nazvanou Praha neni Česko. Mezi další oceněné projekty v této kategorii patř́ italská

8 Markéta Fantová pro Český rozhlas Vltava. (ŠTEFANOVÁ 2019a) expozice s názvem The Prague Experiment - „Tato vtipná expozice je pojata jako odvážná imerzivní laboratoř, která aktivuje prostorovou představivost účastníků a diváků prostřednictvím hry a interakce. " - a filipínská expozice Passing Through: Lines and Borders: „Pro některé z nás jsou hranice propustné, ale pro jiné zůstávají nepřekonatelné. Tento projekt dokumentuje emocionální dopad kontroly hranic a imigrace. ${ }^{10}$

\section{Praha není Česko}

Jaká je identita města? Žádný rozumný moderní člověk neočekává, že ji lze nalézt v sek-

9 Dostupné online http://www.pq.cz/cs/vitezioceneni/.

10 Dostupné online http://www.pq.cz/cs/vitezioceneni/. 
ci komentárư na stránce TripAdvisor.com - ale jak tedy můžeme poznat ducha místa? Autoři projektu se snaží udržet si svou identitu, přestože žijí v turistické destinaci. Jejich týmu se dokonce podařilo zmást některé členy poroty, kteří si instalaci spletli se skutečným turistickým informačním centrem. ${ }^{11}$

Těmito slovy zdůvodnila mezinárodní porota $P Q 2019$ udělení Ocenění za Imaginaci ve Studentské výstavě projektu Praha neni Česko, jenž byl pro letošní ročník přehlídky vytvořen převážně studenty scénografie na Janáčkově akademii v Brně. Konkrétně jde o skupinu Intelektrurálně, kterou tvoří Anna Chrtková, Andrea Dudková a Jan Matýsek a která se svým návrhem projektu Praha neni Česko uspěla v otevřené výzvě na ztvárnění české expozice ve studentské sekci na letošním ročníku $P Q$, vypsané Institutem umění - Divadelním ústavem.

Expozice se zakládala na myšlence vytvoření svébytné scénografické struktury, jež by mohla existovat jak v rámci výstavního prostoru, tak v prostředí okolní krajiny, zejména té mimopražské. Návštěvník se mohl v první úrovni setkat se stánkem cestovní kanceláře, který svou formou i obsahem ztělesňoval objekt výstavně-veletržním prostorům nesporně vlastní. Pracovníci stánku zde totiž představovali a ke koupi nabízeli několik výletů - zájezdů, organizovaných různými uměleckými týmy. Pokud návštěvník nabídku přijal a výletu se zúčastnil, stal se z něj spolu-aktér v další expozici, „kurátorované realitě“ dané lokality. Projekt Praha neni Česko totiž reagoval na odtrženost malých lokálních center, vesnic a jejich obyvatel od hlavního

11 Dostupné online http://www.pq.cz/cs/vitezioceneni/. města, na často velmi hlubokou názorovou propast mezi obyvateli velkoměst a venkova. Prostřednictvím organizovaných výletů bylo proto možné navštívit například periferii města Ústí nad Labem, a to v režii umělecké skupiny Czechia, nebo strávit den v brdských lesích v pojetí studentů Katedry alternativního a loutkového divadla pražské DAMU. ${ }^{12}$

Jak vysvětlují autoři projektu,

[...] vyvedením návštěvníků $\mathrm{PQ}$ mimo Prahu se chceme pokusit o dialog s reálným prostředím, skutečnými lidmi. Základní myšlenkou bylo dostat umění (často širokou veřejností vnímané jako „elitářské“) ven z velkoměstských galerií a divadel a napojit ho na lokální úroveň. V podobě poznávacích výletů má koncept potenciál stát se platformou pro oboustrannou výměnu zkušeností mezi autory, návštěvníky („turisty“) a veřejností (obyvateli měst a vesnic mimo Prahu). "13

Další úroveň expozice tvořil virtuální obraz právě probíhající akce; každý výlet byl totiž jejich delegátkami natáčen, přičemž se záznam okamžitě přenášel do stánku cestovní kanceláře, kde byl na velkých obrazovkách simultánně promítán. Expozice se tedy skládala $z$ několika vzájemně se prolínajících akcí, přičemž fungovala především jako smyslový i fyzický zážitek. Pivo, les, jahody, továrna, místní obchod - vše se stává scénografií. Klíčovými pro takové pojetí expozice se stali především performeři a diváci, respektive spolu-aktéři, jejichž interakcí se vytvářel proměnlivý obraz daného prostředí. Scénografie zde představovala prostředek k vytvoření kontextu i samotné

12 Více např́ílad na http://www.prahanenicesko.cz/.

13 Anotace projektu Praha neni Česko. Autoři: Anna Chrtková, Andrea Dudková, Jan Matýsek. 

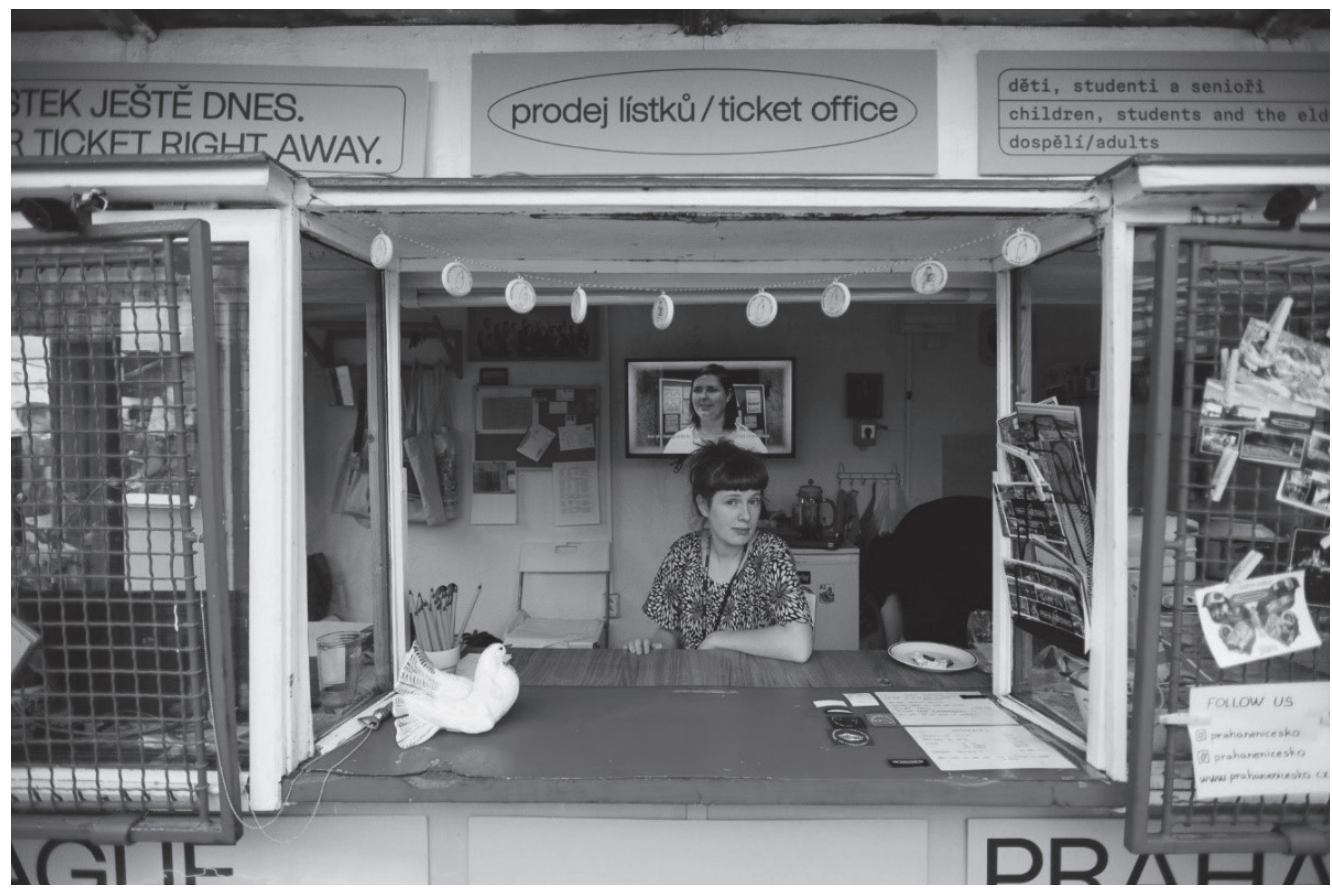

Obr. 7: Foto Jan Hromádko

akce, bez něhož by zvolené prostředí nedisponovalo kýženými významy.

V základní myšlence se pojednávanému projektu podobal i druhý český reprezentant, a sice scénograficky rozsáhlý koprodukční projekt $C A M P Q$, jenž vznikl pro soutěžní Výstavu zemí a regionů. I zde se první část projektu odehrávala v Průmyslovém paláci, kde se mohli návštěvníci setkat se simulací terminálu, či náborového střediska, jehož aktéři vyzývali $\mathrm{k}$ návštěvě Ostrova Štvanice. Návštěvníci $P Q$ se tam mohli vydat bud' během dne a prohlédnout si výstavní verzi projektu, nebo se mohli ve večerních hodinách zúčastnit imerzivní inscenace, kterou níže přibližuje Tomáš Kubart.

\section{Bibliografie}

Programová brožura PQ 2019. 2019. Praha: Institut umění - Divadelní ústav, 2019.

ŠTEFANOVÁ, Veronika. 2019a. Imaginace, Proměny a Reflexe. Začíná Pražské Quadriennale. Český rozhlas Vltava (6. 6. 2019) [online]. [cit. 2019-08-22]. Dostupné online https:// vltava.rozhlas.cz/imaginace-promeny-a-reflexe-zacina-prazske-quadriennale-7958276.

ŠTEFANOVÁ, Veronika. 2019b. Jak se dá prožít scénografie? Odpověd' přináší letošní Pražské Quadriennale. Český rozhlas Vltava (12. 6. 2019) [online]. [cit. 2019-08-22]. Dostupné online https://vltava.rozhlas.cz/jak-se-da-prozit-scenografie-odpoved-prinasi-letosni-prazske-quadriennale-7961327. 